\title{
Bridging continents; Hantaviruses of Europe and Asia Minor
}

\author{
Kıtalararası köprü; Avrupa ve Küçük Asya’nın Hantavirüsleri
}

Paul HEYMAN ${ }^{1}$, Christel COCHEZ¹ ${ }^{1}$ Gülay KORUKLUOĞLU², Ayșegül GÖZALAN², Yavuz UYAR², Åke LUNDKVisT ${ }^{3}$

\section{ÖZET}

Hantavirüs cinsinin üyeleri, Bunyaviridea ailesi içinde yer alır ve Avrasya kıtasında renal sendromla seyreden kanamalı ateș (RSKA) ve Amerika kıtasında hantavirüs Kardiyopulmoner Sendrom (HKPS)'un etkenidir. Kemirgenler -ve son olarak keșfedilen insektuvarlar (böcek yiyiciler)- șimdiye kadar keșfedilen hantavirus serotipleri için tașıyıcı olarak rol oynarlar. Avrupa alt kıtasında bütün bilinen hantavirüs taşıyıcıları Türkiye'de de mevcuttur. Bu nedenle, olasılıkla gelecekte daha birçok hantavirüs serotipi Türkiye'de tespit edilebilecektir. Avrupa kıtası üzerinde, RSKA on binlerce bireyi etkileyen endemik bir zoonozdur. Türkiye'nin Karadeniz bölgesinde 2009 yılında, hantavirüs hastalığının ilk salgını yașanmıștır. Bu olay için, bölgedeki meteorolojik veriler önemli ölçüde ipuçları sağlayabilir: Temmuz-Ağustos-Eylül aylarındaki ortalama sıcaklık değerleri ve aylık ortalama yağıș oranları önceki yıllara göre daha yüksektir. Bartın ilinde 2008 ve 2009 yılları aynı zamanda kayın (Fagus sylvatica) ağaçları için meșe palamudu yılı (mast years) idi. Bu olaylar (uygun iklim koșulları ve gıda bolluğu), 2008 ve 2009 yıllarında salgın meydana gelen bölgelerde muhtemelen Bank Vole ve diğer tohum yiyen kemirgenlerde bir artışa yol açtı. Tarım ve ormancılık uzmanları tarafından sağlanan bilgilerle de kemirgen nüfus artıșı teyit edilmiștir. Bu makalede Avrupa ve Türkiye'deki hantavirüs sorununa genel bir bakış sağlamayı amaçladık.

Anahtar Sözcükler: Hantavirüs, Puumala, Dobrava, Avrupa, Türkiye

\section{ABSTRACT}

Members of the genus hantavirus, family Bunyaviridae, are the causative agents of Hemorrhagic Fever with Renal Syndrome (HFRS) on the Eurasian continent and Hantavirus Cardiopulmonary Syndrome (HCPS) on the American continent. Rodents -and as was recently discovered also insectivores- act as carriers for the so far discovered hantaviral serotypes. All known hantavirus carriers from the European sub-continent are also present in Turkey. Therefore the possibility exists that in the future more hantavirus serotypes will be detected in Turkey. On the European subcontinent, HFRS is an endemic zoonosis that affects tens of thousands of individuals. In the year 2009 Turkey experienced his first outbreak of hantavirus disease in the Black Sea region. The meteorological data from the region provide clues for this event as both the average temperature in JulyAugust-September and monthly average precipitation were significantly higher than in previous years. The years 2008 and 2009 were also mast years for the beech (Fagus sylvatica) in the Bartin province. These events (favorable climatic conditions and food abundance) probably led to an abundance of bank voles and other seed-eating rodents as witnessed by information provided by agricultural and forestry experts concerning an increase in rodent populations in 2008 and 2009 in the regions where the outbreak occurred. Here we provide an overview of the hantavirus problem in Europe and Turkey.

Key Words: Hantavirus, Puumala, Dobrava, Europe, Turkey

\footnotetext{
' Research Laboratory For Vector-borne Diseases, Queen Astrid Military Hospital, Brussels, BELGIUM

${ }^{2}$ Refik Saydam National Public Health Agency, Ankara, TURKEY

${ }^{3}$ Swedish Institute for Infectious Disease Control and Karolinska Institute, Stockholm, SWEDEN

İletişim/ Corresponding Author : Paul HEYMAN

Research Lab. For Vector-borne Diseases, Queen Astrid Military Hospital, Brussels, BELGIUM

Tel : +0032 $22644044 \quad$ E-posta/E-mail : paul.heyman@mil.be

Geliş Tarihi / Received : 08.02.2011 Kabul Tarihi / Accepted : 14.02 .2011
}

DOI ID : 10.5505/TurkHijyen.2011.33254 


\section{INTRODUCTION}

Hantaviruses (genus Hantavirus, family Bunyaviridae) are carried by rodents and insectivores, in which they have coevolved for millions of years. In rodents, hantaviruses are found both in Cricetidae (subfamilies Arvicolinae, Neotominae and Sigmodontinae) and in Muridae rodents (subfamily Murinae). Hantaviruses and their rodent hosts evolved phylogenetically in parallel (1). This observation suggests a long-lasting co-evolution, although occasional host switches have occurred. Several new hantaviruses have been very recently detected in insectivores (Laihia virus (LAIV) in Neomys fodiens, Asikkala virus (ASIV) in Sorex minutus, Sewis virus (SWSV) in Sorex araneus in Finland) in addition to the insectivore-borne Thottapalayam virus (TPMV) carried by the Asian house shrew (Suncus murinus) which is still the only insectivore-borne hantavirus that was isolated so far (2).

Hantaviruses are enveloped, single-stranded, negative sensed and tri-segmented RNA viruses. The small (S) segment encodes for the nucleocapsid protein, the medium $(M)$ segment for the two envelope glycoproteins ( $G n$ and $G c$ ) and the large (L) segment for the RNA polymerase (3).

In Europe, hemorrhagic fever with renal syndrome (HFRS) is caused by Dobrava virus (DOBV), carried by Apodemus flavicollis (yellow-necked mouse). A milder form of HFRS -nephropathia epidemica- is caused by Puumala virus (PUUV), carried by Myodes glareolus (bank vole), and -probably- by Saaremaa virus (SAAV), carried by Apodemus agrarius (the striped field mouse). It should be noted that the $A$. agrarius associated strains in Central-Europe and Russia have been shown to be phylogenetically distinct from the north-eastern European Saaremaa strains as well as from A. flavicollis associated strains (or DOBV-Af lineage) or Apodemus ponticus-associated strains (or DOBV-Ap). By routine serological diagnostic tools -and even routine RT-PCR- it is currently impossible to differentiate between the different viruses.
Comparing the viral sequences is necessary. In Asia, Hantaan virus (HNTV), Amur virus (AMRV) carried by $A$. agrarius (striped field mouse) and Apodemus peninsulae (Korean field mouse) respectively, and Seoul virus (SEOV) transmitted by Rattus rattus and Rattus norvegicus (black and brown rat) cause HFRS (1).

In Turkey, HFRS is a recently emerged disease and -so far- only DOBV and PUUV have been proven to cause human illness. It has to be noted however that all known European hantavirus carriers are also present in Turkey; therefore the possibility exists that in the future more hantavirus serotypes will be detected in Turkey. Muranyi already reported in 2005 the circulation of PUUV, SAAV and TULV (host as well as virus) in Turkey, although no reference to the origin of these data was given (4). Hantavirus infection in humans occurs when one comes in contact with infected rodent excreta; this usually takes place when the excreta dry out and get airborne as dust particles during cleaning activities, stacked wood manipulation or other activities that create dust clouds. Infection through rodent bite is also a possibility but was rarely reported (1).

\section{Defining the geographical region}

Although geographically a subcontinent, Europe is historically and culturally considered a continent, forming the western part of the Eurasian supercontinent. The -therefore artificial- border with Asia runs from the Urals to the Caspian and the Black Sea.

Asia Minor -a peninsula of western Asia- refers to the land mass known as Anatolia, which roughly occupies the area covered by present day Asian Turkey. It is washed by the Black Sea in the north, the Mediterranean Sea in the south, and the Aegean Sea in the west. The Black and Aegean seas are connected by the Sea of Marmara by means of two straits, the Bosporus and the Dardanelles. In the East Turkey borders Georgia, Armenia, Iran, Iraq and Syria, in the West Greece and Bulgaria. 
The Northern part of Turkey, where climate and biotope resemble that of Western and Central Europe, consists of the Kırklareli, Tekirdağ (the European part of Turkey, also referred to as Thrace) and İstanbul provinces (with the Bosphorus as geographical frontier between Europe and Asia Minor) in the Marmara region and -from West to East along the Black Sea- the Düzce, Bolu, Zonguldak, Karabük, Bartın, Kastamonu, Sinop, Çorum, Samsun, Amasya, Ordu, Tokat, Giresun, Trabzon, Gümüșhane, Bayburt, Rize and Artvin province. The Bolu, Karabük, Çorum, Amasya, Tokat, Gümüșhane and Bayburt provinces have no border with the Black Sea but are situated against the Koroglu-Kaçkar mountain ranges. The North Anatolian Fault -one of worlds most energetic earthquake zones- runs through the entire area (5).

The Black Sea region has a rocky coast, inland access from the coast is limited to narrow valleys because the Koroglu and Kaçkar mountains form a wall separating the coast from the interior. The northern slopes of the mountain ridges carry dense deciduous and evergreen forests.

A number of fertile, intensely cultivated river deltas and mountain slopes are situated in the region. The Samsun area is a major tobacco- and citrusgrowing region, Trabzon is world-renowned for the production of hazelnuts, Giresun for cherries and the Rize region for tea culture. The mild, damp oceanic climate of the Black Sea coast favours farming. The western part of the Black Sea region (Zonguldak) is a center of coal mining and heavy industry. The Black Sea coast is the only region of Turkey that receives high precipitation throughout the year, up to 2,500 millimeters annually (6). The Black Sea region counts 8,4 million inhabitants, half of which live in cities and the other half in rural areas. Because of the above described particularities the provinces from the Northern part of Turkey are likely candidates for the occurrence of hantavirus infections (7).
The rodents

In terms of number of species, rodents make up the largest order of mammals, according to Wilson\&Reeder's 3rd edition of Mammal Species of the world; there are about 2.277 species of rodents known (8). Although almost omnipresent as an organism, significant population sizes of endemic species are not necessarily present everywhere and always i.e. in some regions rodents are numerous or rare depending on biotic and abiotic factors that facilitate or prevent their occurrence. Most European countries possess 10 to 20 endemic rodent species.

Not taking introduced species into account, Europe counts 23 insectivore species ( 3 hedgehog, 5 mole and 15 screw species) and 56 rodent species (41 mice and voles, 2 birch mice, 6 dormice, 1 beaver and 6 squirrel species) (8). With respect to both Rattus norvegicus and $R$. rattus, it should be noted that these species should be considered as introduced species in Europe and Turkey. Both species originated in the China region and came -via India, Persia, and Egypt- to Europe along ancient trade routes. $R$. rattus arrived well before $R$. norvegicus, skeletal remains of the first were recovered in Corsica, dating from between the fourth and second centuries $B C$ and in the United Kingdom from around the third century $A D$ (9). R. norvegicus arrived centuries later but the exact time of their arrival is unknown. Norway rat remains have been discovered at a medieval settlement in Northern Germany, which was occupied from the 9th to the 13th centuries AD (10), and at Bodenteich castle in the district of Uelzen, Lower Saxony, dating to the medieval and post-medieval period. The brown rat, being much more resistant to cold, adaptable and not restricted to living in human shelters as is the case for the black rat, gradually out-competed the smaller, less aggressive black rat in most temperate climate zones (11).

In the early Oligocene (34 tot 23 millions of years ago (mya)), members of the Dipodidae family (birch mice, jerboas, and jumping mice) migrated into 
Anatolia from central Asia. In the Late Oligocene, several migration waves originating from Europe and central Asia again enter Anatolia. The Turkish Miocene (23 to 5 mya) rodent record seems to differ significantly from the European while the Early Miocene Anatolian rodent record also differs significantly from the Asian record. The Anatolian rodent assemblage thus seems influenced by consecutive migration waves -driven by climatic and faunal changes- from Europe as well as Asia (12). Hantaviruses co-evolved with their carrier species for millions of years and probably also "made the journey" together. At present, Turkey counts 17 endemic insectivore species (two hedgehog, two mole and 13 shrew species) and 45 rodent species (five squirrels, six dormice, two jerboa, three mole rat, three hamster, 13 vole and 13 mice species). Yiğit and colleagues describe the present-day Turkish rodent assemblage in detail in their book (13). Several other authors have contributed to the description of rodent populations on provincial level in Turkey (14-17). Laakkonen and colleagues trapped wild rodents in the Trabzon, Rize and Izmir provinces in northeastern and western Turkey. Antibodies to PUUV virus were detected in four out of 65 Microtus spp. voles (one Microtus guentheri, one Microtus roberti and two Microtus rossiaemeridionalis). All Apodemus spp. mice tested negative for antibodies to SAAV. This serological survey confirmed the presence of -amongst other rodent-borne viruseshantaviruses in their natural hosts in Turkey for the first time (18). Microtus voles are however an unexpected and unusual host for PUUV. Responding to the recent outbreak and the results obtained by several seroepidemiological studies that pointed to the circulation of PUUV and DOBV viruses in the affected regions, the Refik Saydam National Public Health Agency (RSNPHA) has initiated a rodent monitoring project.

The driving forces behind hantavirus epidemics

As each hantavirus is carried by a specific rodent species, the population density and subsequently the total carrier species biomass will determine the likeliness for humans to come into contact with the virus that is released in the excreta of infected rodents.

Biotic and abiotic factors, but especially climatic factors trigger rodent population increase $(19,20)$. Most rodent species show cyclic population dynamics, i.e. at a certain moment the population will increase to a high number of individuals, the prevalence of circulating hantaviruses will increase because of increased inter-species contacts. The high number of rodents and the high prevalence of virus in their population in turn increases the probability for humans to come in contact with the virus. Although the exact reasons are still unclear, rodent populations crash after these peaks; whether due to diseases, predators, disturbed interactions, Depending on the geographical region, rodent population and hantavirus dynamics are different.

In Northern Europe the rodent population cycles are said to be driven by a predator-prey mechanism. In Western Europe mast events (years with increased seed crops from a number of trees i.e. oak, beech , hornbeam, maple, alder, etc) are believed to be the triggering force.

In the affected area in Turkey the climate is hot in the summer and cool in the winter. The meteorological data over the past 30 years suggest that the average annual temperature is $12.5^{\circ} \mathrm{C}$, annual precipitation $87.1 \mathrm{~mm}$ and annual humidity $79.2 \%$. The monthly average precipitation in $2008(91.9 \mathrm{~mm})$ was higher than 2006 (72.1 mm) and 2007 (73.1 mm) (Turkish State Meteorological Service), while the average precipitation in the first four months of 2009 (114.0 $\mathrm{mm}$ ) was higher than many past years. Moreover, the average temperature in July-August-September $\left(21.6^{\circ} \mathrm{C}, 21.4^{\circ} \mathrm{C}, 22.1^{\circ} \mathrm{C}\right.$ and $21.5^{\circ} \mathrm{C}$ respectively) in 2005-2008 is higher than the average of summer months $\left(20.4^{\circ} \mathrm{C}\right)$ of several past years. The years 2008 and 2009 were mast years for the beech tree in Bartin province (Ozkazanc N.K, pers. communication). 
This apparently led to an abundance of bank voles and other seed-eating rodents. According to the information provided by agricultural and forestry experts, the rodent population density in the Bartin province began to rise in 2008 and the increase continued during 2009. This probably resulted in increased vector-host contact; the outcome was the first hantavirus outbreak recorded in Turkey. It remains unclear whether the virus was previously present in these areas at very low levels or in small ecological niches, thereby presenting only a negligible risk for humans, or whether it has been newly introduced.

\section{Biotopes}

Oak (Pedunculate Oak (Quercus robur), Sessile Oak (Quercus petraea) and Turkey Oak (Quercus cerris) grows in almost any part of the country. Beech (Oriental Beech (Fagus orientalis) and European Beech (Fagus sylvatica)), is mostly found in northern regions, but is also present as far south as the Amanos mountains (Hatay province, south-central Turkey). Hornbeam (European hornbeam (Carpinus betulus), Oriental Hornbeam (Carpinus orientalis)) -essential in Central European forests for maintaining local rodent population- grow in Thrace (the European part of Turkey), the Aegean, Marmara, North and East Anatolian regions. Alder (Oriental alder (Alnus orientalis) and bearded alder (Alnus barbata)) grows in a large area in Thrace, the Marmara and West and East Black-Sea regions. Together with oak, beech and hornbeam, it forms the mixed forests that are able to sustain important rodent populations (General Directorate of Forestry, http://www.ogm. gov.tr/)

As mentioned before, intensive agricultural activities and farming i.e., hazelnut, cherries, various fruits, vegetables and tea production combined with a mild, oceanic climate and the available forests, the Black Sea coast favors the rodent populations considerably more than other Turkish regions.

\section{Hantavirus infections}

In Europe hantavirus infections are described for several decades, first in Sweden but from the '80ties on human cases were reported from all countries in the northern, western and eastern part of the continent. Exceptions are Spain, Italy and most Mediterranean isles (Malta, Cyprus, Balearic islands, Corsica, Sicily, etc).

Northern and Western Europe have been particularly vulnerable for hantavirus infections in the past three decades. After 1981, when PUUV was discovered in Finland (21) and the first diagnostic tools for hantaviruses became available, gradually more and more cases were detected -first in Scandinavia and Russia but later on also in Belgium, France- up until a level of hundreds of cases per year. With the availability of better and more reliable diagnostics in the '90ties, more and more countries followed. While PUUV infections were relatively benign (mortality $<0.1 \%$ ), a new and deadly hantavirus (DOBV, mortality rate 5-10\%)) was discovered in 1992 in Slovenia (22). Now it seems clear that PUUV and DOBV are responsible for the bulk of the hantavirus cases in Europe. Noteworthy is also that especially for PUUV infections only five to ten percent of the infected individuals also develop clinical disease, meaning that the number of reported cases has to be multiplied with a factor 10 to 20 in order to have an idea of the yearly number infections. A Finnish report stated that the yearly number of reported cases only represents around $30 \%$ of the actual number of clinically ill individuals. This is probably due to the fact that PUUV infection can be very mild and often goes unrecognized a such. A detailed summary of the European situation for the period 1990-2006 and an update of the period 2006 up until mid 2010 was published in Eurosurveillance respectively in 2008 and $2011(2,23)$.

Turkey came, hantavirus-wise, in 2009 in the spotlights when an outbreak in the Black Sea region, more specifically in the provinces Zonguldak 
and Bartin, occurred with a fatality rate amongst hospitalized patients of $8 \%$ (24). This fatality rate pointed rather to a DOBV-like hantavirus than to a PUUV-like virus. Also remarkable was that -in a seroepidemiological study performed in an at-risk group in the Bartin province- a seroprevalence of $5.2 \%$ was found (24). Except for some hyper-endemic regions in Scandinavia where seroprevalence in the normal population can be as high as $15 \%$, the overall seroprevalence in European countries ranges between 1 and $2 \%$ (1). Kaya and colleagues (25) reported two cases from Eastern Turkey and Oncul and co-workers reported a fatal case of DOBV infection in the urban environment of Istanbul (26).

Human hantavirus cases in Turkey were earlier reported by several authors (although the results did not always unequivocally confirm hantavirus disease). Kavukcu et al. reported already in 1997 cases from the Aegean region (27), this study tested serum samples from 200 patients with acute or chronic renal failure and found initially 24/200 positive for IgG antibodies against DOBV. A Western Blot (WB) test further confirmed 7 out of the initial 24 patients as reactive for DOBV IgG antibodies (28).

\section{Conlusions}

Intra- and inter-species interactions between rodent populations from Europe and Asia have occurred for millions of years and are probably still ongoing. Nowadays, worldwide decreasing biodiversity, increasing pressure on fauna and flora due to the presence of nearly seven billion humans on a planet that is hardly able to support that number, will probably have more impact on wildlife in the few decades to come than evolution had in the last few millions of years.

Hantavirus infection - a zoonotic disease- has its origin in the same framework. Whenever the probability of human-wildlife contact increases to a certain threshold, the pathogens carried by both species begin to influence the opponent species.
In our case, the rodent-borne hantaviruses begin to cause disease in humans. Hantavirus infections have probably been around for thousands of years, it is however only relatively recently that they draw the attention of the medical community. The emergence of this disease in Turkey is not surprising and was -in a country adjacent to regions where hantavirus infections are endemic since decades- to be anticipated.

The circulation of the same viruses (PUUV, DOBV) that cause disease in Europe was -based on available paleontological rodent records (12)- also to be expected. The Late Quaternary climate history of the Eastern Mediterranean region as derived from pollen data shows two main events: the Younger Dryas period (11,000-10,000 years before present (YBP)), when the climate was very arid and cold, and a phase from 9,000 to 6,000 YBP where for instance the abundance of deciduous oak pollen peaks indicating an increasingly warmer, more humid climate optimum with very mild, frost-free winters. After 6,500 YBP, other deciduous trees display maximum pollen abundance indicating still abundant precipitation the year round, but cooler winters. This evolution of the climate and vegetation record matches that of the rest of the Eurasian continent during the same period $(29,30)$. It is thus reasonable to assume that hantaviruses and their carriers experienced a similar evolution in the entire region of interest for this paper. The Eastern Mediterranean region is regarded as the crossroad for mammal exchanges between Asia, Europe and Africa during the Neogene/Quaternary (31).

While hantavirus infections gradually became an increasing public health problem in Europe during the last three decennia, the problem is new for Turkey. Acquiring a viral infection, which is transmitted via aerosol -like HFRS- requires close contact between the vector and the host, this is best accomplished when both vector and host population densities are high. The population density in European Union is stable and on average 113 inhabitants $/ \mathrm{km}^{2}$, ranging 
from 81 in Greece to 393 in The Netherlands, with a peak of 16,000 inhabitants $/ \mathrm{km}^{2}$ in Monaco (http://epp.eurostat.ec.europa.eu/portal/page/ portal/eurostat/home) while in Turkey the average population density increased from 27 inhabitants $/ \mathrm{km}^{2}$ in 1950 to 79 in 1990 and 93 in the year 2002. Taking into account that $45 \%$ of the total population inhabits the regions (Black Sea coastal regions, Aegean region) where the virus appears to circulate, it thus seems that a comparable average population density level as in the European Union is reached which may have triggered the emergence of hantavirus infections.

\section{REFERENCES}

1. Heyman P, Vaheri A, Lundkvist $\AA$, Avsic-Zupanc T. Hantavirus infections in Europe: from virus carrier to major health problem. Exp Rev of Anti-infect Ther, 2009; 7(2): 1-7.

2. Heyman P, Ceianu C, Christova I, Tordo N, Beersma M, Alves MJ, et al. ENIVD-CLRN report on nephropathia epidemica (NE) and hemorrhagic fever with renal syndrome (HFRS) in Europe. Euro Surveill. Accepted Jan 2011.

3. Hjelle B, Torrez-Pérez F. Hantaviruses in the Americas and Their Role as Emerging Pathogens. Viruses, 2010; 2:2559-86.

4. Muranyi W, Bahr U, Zeier M, van der Woude FJ. Hantavirus infection. J Am Soc Nephrol, 2005; 16: 3669-79.

5. Atalay I. Mountain ecosystems of Turkey. Proceedings of the 7th International Symposium on high Mountain Remote Sensing Cartography, ICA 2002, Bishkek, Kyrgys Republic, Kartographische Bausteine, Band 28 (2004); Institute for Cartography, Dresden University of Technology, Germany Eds: M.F. Buchroithner (Institute for Cartography, Dresden University of Technology, Germany), 2004: pp 29-38.

6. Sensoy E, Demircan M, Ulupinar Y, Balta I. Climate of Turkey. Turkish State Meteorological Service. Eastern Mediterranean Climate Center. 2008. http://emcc.dmi.gov.tr/climate-analysis.aspx

7. Atalay I. The Effects of Mountainous Areas on Biodiversity: A Case Study from the Northern Anatolian Mountains and the Taurus Mountains. Grazer Schriften der Geographie und Raumforschung Band 41/2006. Institute for Geography and Regional Science, Karl Franzens University Graz, Austria, 2006: pp. 17-26.
Sero-epidemiologic studies in the general population in order to define the true prevalence and risk factors for acquiring hantavirus infection in order to increase awareness for this disease in Turkey are planned. Risk analysis and -assessment and the serotyping of hantaviruses in humans and their principal hosts in different geographical regions in Turkey is also warranted.

\section{Acknowledgments}

This work was supported by grant WB-28 of the Belgian Ministry of Defence.
8. Wilson DE, Reeder DM. (editors). Mammal Species of the World. A Taxonomic and Geographic Reference Johns Hopkins University Press. 3rd edition, 2005.

9. McCormick M. Rats, communications and plague: Toward an ecological history. J Interdiscipl Hist, 2003; 34(1); 1-25.

10. König S. The medieval settlement of Klein Freden near Salzgitter from the 9th - 13th century. Settlement - manor- horse husbandry. In: Materialhefte zur Urund Frühgeschichte Niedersachsens. Verlag Marie Leidorf GmbH, Rahden/Westf, 2007.

11. Twigg G. The Black Death: a biological reappraisal. Batsford Academic and Educational. (ISBN 0713446188), London, 1984.

12. Wessels W. Miocene rodent evolution and migration. Muroidea from Pakistan, Turkey and Northern Africa. Geologica Ultraiectina. Doctoral Tesis, (ISBN 978-90-5744-170-7), University of Utrecht, 2009.

13. Yiğit N, Çolak $E$, Sözen $M$, Karataș A. Rodents of Turkey. (Eds. Ali Demirsoy) Meteksan Co. Ankara, Turkey, 2006.

14. Felten H, Spitzenberger F, Storch G. Zur Kleinsaugerfauna West-Anatoliens. Teil II. Senckenbergiana Biol, 1973; 54: 227-90.

15. Pamukoğlu N, Albayrak i. The Rodents of Kastamonu Province (Mammalia; Rodentia). Comm. Faculty of Sci., Univ. of Ankara, Serie C, 1996; 14(1-2): 1-22.

16. Yiğit N, Çolak E. Contribution to the geographic distribution of rodent species and ecological analyses of their habitats in Asiatic Turkey. Turk J Biol, 1998; 22: 435-46 
17. Kefelioglu H, Tez C, Gündüz Ü. The Taxonomy and Distribution of Apodemus agrarius (Pallas, 1771) (Mammalia: Rodentia) in the European Part of Turkey. Turk J Zool, 2003; 27:141-6

18. Laakkonen J, Kallio-Kokko H, Oktem MA, Blasdell K, Plyusnina A, Niemimaa J, et al. Serological survey for viral pathogens in Turkish rodents. J Wildl Dis, 2006 ;42(3):672-6.

19. Tersago K, Verhagen $R$, Servais A, Heyman P, Ducoffre G, Leirs H. Hantavirus disease (nephropathia epidemica) in Belgium; effects of tree seed production and climate. Epidemiol Infect, 2009; 137:250-6.

20. Tersago K, Verhagen $R$, Vapalahti $O$, Heyman $P$, Ducoffre G, Leirs H. Hantavirus outbreak in Western Europe: reservoir host infection dynamics related to human disease patterns. Epidemiol Infect, 2010; 10:1-10

21. Brummer-Korvenkontio $M$, Henttonen $H$, Vaheri A. Hemorrhagic fever with renal syndrome in Finland: ecology and virology of nephropathia epidemica. Scand J Infect Dis, 1982; 36:88-91.

22. Avsic-Zupanc T, Xiao SY, Stojanovic R, Gligic A, van der GG, Leduc JW. Characterization of Dobrava virus: a Hantavirus from Slovenia, Yugoslavia. J Med Virol 1992; 38(2):132-7.

23. Heyman P, Vaheri A, the ENIVD members. Situation of hantavirus infections and haemorrhagic fever with renal syndrome in European countries as of December 2006. Euro Surveill, 2008;13(28): $\mathrm{pii}=18925$.
24. Ertek M, Buzgan T. (On behalf of Refik Saydam National Public Health Agency; Ministry of Health, Ankara, Turkey.) An outbreak caused by hantavirus in the Black Sea region of Turkey, January-May 2009. Euro Surveill, 2009; 21;14(20). pii: 19214.

25. Kaya S, Yilmaz G, Erensov S, Yağçı Çağlayık D, Uyar Y, Köksal I. Hantavirus infection: two case reports from a province in the Eastern Blacksea Region, Turkey. Mikrobiyol Bul, 2010; 44(3):479-87.

26. Oncul O, Atalay $Y$, Onem $Y$, Turhan V, Acar A, Uyar $\mathrm{Y}$, et al. Hantavirus infection in istanbul, Turkey. Emerg Infect Dis, 2011; 17(2):303-4.

27. Kavukcu S, Türkmen M, Salman A, Soylu A, Amsari DTC. What is the risk of nephropathy associated with hantavirus in Agean region? J Turkish Nephrol, 1997;3-4: 131-5.

28. Öktem IMA. Hantavirus ve kene ile bulasan ensefalit virusu infeksiyonlari. ANKEM Derg, 2009; 23(2): 245-48.

29. Rossignol-Strick M. Late Quaternary climate in the Eastern Mediterranean Region. In: Paléorient, 1993; 19 (1):135-52.

30. Hewitt G. The genetic legacy of the Quaternary ice ages. Nature, 2000; 405:907-13.

31. Koufos GD, Kostopoulos DS, Vlachou TD. Neogene/ Quaternary mammalian migrations in Eastern Mediterranean. Belg J Zool, 2005;135 (2):181-90. 